\title{
Chebulagic acid from Terminalia chebula causes G1 arrest, inhibits NFkB and induces apoptosis in retinoblastoma cells
}

\author{
Naresh Kumar ${ }^{\dagger}$, Gangappa D ${ }^{\dagger}$, Geetika Gupta and Roy Karnati
}

\begin{abstract}
Background: Plants are the valuable source of natural products with important medicinal properties. Most of the approved anti cancer drugs have a natural product origin or are natural products. Retinoblastoma is the most common ocular cancer of children. Although chemotherapy is the preferred mode of therapy, a successful treatment for retinoblastoma requires enucleation. Chebulagic acid (CA) from Terminalia chebula was shown to have anti-proliferative properties in the studies on cancerous cell lines. Due to anti cancer properties of CA and due to limitation in treatment options for retinoblastoma, the present study is undertaken to understand the role of CA on the proliferation of retinoblastoma cells.
\end{abstract}

Methods: Anti proliferative potential of CA was determined by MTT assay. The expression levels of various cell death mediators in retinoblastoma cells with CA treatment were assessed by Western blotting. Flowcytometer analysis was used to estimate the mitochondrial membrane potential (MMP) and to determine the percentage of cells undergoing apoptosis.

Results: The present study showed CA inhibited the proliferation of retinoblastoma cells in a dose dependent manner. CA modulated MMP, induced release of Cytochrome $C$, activated caspase 3 and shifted the ratio of BAX and $\mathrm{BCl} 2$ towards cell death. G1 arrest, noticed in CA treated cells, is mediated by the increase in the expression of CDK inhibitor p27. CA treatment also decreased the levels of NFKB in the nucleus. This decrease is mediated by suppression in degradation of IKBa.

Conclusion: CA has shown significant anti proliferative potential on retinoblastoma cells. Our findings clearly demonstrate that CA induces G1 arrest, inhibits NFKB and induces apoptosis of retinoblastoma cells.

Keywords: Chebulagic acid, Retinoblastoma, Apoptosis

\section{Background}

Natural products from plants are considered as a valuable source of active drug substances and a majority of modern drugs. Drugs derived from plants or microbes which are in preclinical development or in clinical phase are discussed in detail elsewhere [1]. In addition to the stand alone natural products, there is also a growing interest in the combination of natural products, being effective or efficacious in a particular pathological condition and such combinations were also approved for human use by

\footnotetext{
* Correspondence: roykarnati@gmail.com

${ }^{\dagger}$ Equal contributors

School of Life Sciences, University of Hyderabad, Gachibowli, Hyderabad 500046, India
}

(c) 2014 Kumar et al.; licensee BioMed Central Ltd. This is an Open Access article distributed under the terms of the Creative Commons Attribution License (http://creativecommons.org/licenses/by/2.0), which permits unrestricted use, distribution, and reproduction in any medium, provided the original work is properly credited. regulatory authorities [2]. Plant derived natural products camptothecin, etoposide, vinblastine and vincristine are all plant derived natural products approved for clinical use in many cancers. Epidemiological studies also show the beneficial effects of some fruit and vegetable diet against cancers $[3,4]$. Bioflavonoids, isoflavonoids, $\beta$ carotenes, phenols, polyphenols, catechins, alkoloids, lectins were shown to have anti proliferative potential in several cancers [5-9].

Natural products alone or in combination with standard drugs were shown to be effective against retinoblastoma [10-12]. Retinoblastoma is the most common ocular tumor of children. In the majority of cases the survival 
rate in retinoblastoma is almost $90 \%$ but successful treatment of retinoblastoma is achieved by enucleation [13]. At present treatment options include radiotherapy, chemotherapy, thermotherapy and brachytherapy [13,14]. Many complications arise due to the conventional therapies such as impaired vision due to cataracts and retinopathy [13], gastrointestinal disorders, neurotoxicity [15-19]. Carboplatin, etoposide and vincristine are synergistically used in chemotherapy of retinoblastoma [13]. Secondary cancers are induced due to the conventional therapies in children of lower age [14,20-22].

Inhibition of the molecular pathways having role in cell proliferation is a widely used strategy in anti cancer drug development. NFkB is an anti apoptotic transcription factor which plays an important role in the cell survival signaling. Interaction with $\mathrm{I}_{\kappa} \mathrm{B}$ makes $\mathrm{NF} \mathrm{KB}_{\mathrm{B}}$ to reside in the cytoplasm as a dimer. Cell proliferation inducers mediate rapid degradation of $I_{\kappa} B$, promotes translocation of $N F \kappa B$ to the nucleus and induces the expression of several anti apoptotic protein including BCL2 family members [23,24]. p27 regulates cell cycle transition and increase in the expression of p27 arrests the cells in G1 phase and restricts entry into S phase. p27 is phosphorylated by CDK 2-cyclin E and this phosphorylation of $\mathrm{p} 27$ results in its degradation through ubiquitin mediated proteosomal degradation [25]. NFKB activity is constitutively required for the survival and proliferation of retinoblastoma cells [26].

Natural products are being explored for effective therapies and to reduce complications due to conventional chemotherapy in retinoblastoma. Few studies were successful in showing anti proliferative potential. Resveratrol inhibits proliferation of retinoblastoma cells by activating mitochondrial mediated apoptosis [27]. Abelmoschus moschatus extracts showed potent anti oxidant and anti proliferative activity in retinoblastoma [10]. Plant derived natural products like peruvoside, ouabain, neriifolin, digoxin, and digoxigenin induced greater than $75 \%$ inhibition in at least one retinoblastoma cell line [11]. Paclitaxel (PTX), a diterpene taxane, induced apoptosis in retinoblastoma cells along with beta lactophone [12].

In our previous studies we have shown CA from Terminalia chebula as a potent suppressor of lipopolysaccharide induced inflammation in mouse macrophages [28]. CA further showed broad spectrum anticancer effects on HCT-15 (colon), COLO-205 (colon) cell lines [29]. Terminalia chebula, a member of the Combretaceae family, native of India, is being used in alternative medicine. The dried fruits are being used for treatment for conditions of asthma, cough, bloody stools, heart and bladder disease [30]. The fruits are rich in high molecular weight tannins [31,32]. Benzopyran tannins are one of the major components in the fruits of Terminalia chebula. CA, a benzopyran tannin, was reported as a COX-2/5-LOX dual inhibitor [29]. CA has been shown to inhibit ROS generation [33] and anti- hyperglycemic activity [34]. CA was also reported to alleviate arthritis in mice models [35] and inhibited LPS-induced Nitric oxide [36]. CA and punicalagin were shown to inhibit HSV-1 entry in A549 human lung cells by preventing binding, penetration, and cell-to-cell spread [37]. In addition to these reported studies, CA is the main constituent of Triphala, a well known ayurvedic medicine used to treat allergies and common health disorders in India.

Due to several important medicinal properties of CA and limitation of the current conventional therapies in retinoblastoma, the present study is undertaken to understand the effect of CA on the proliferation of retinoblastoma cells and elucidate the molecular mechanisms involved.

\section{Methods \\ Chemicals}

DMEM, FBS, Rhodamine 123, Propidium iodide were purchased from Gibco BRL. MTT [3-(4,5-dimethylthiazol-2-yl)-2,5-diphenyl-2H-tetrazolium bromide], protease inhibitor cocktail and $\mathrm{TMB} / \mathrm{H}_{2} \mathrm{O}_{2}$, DAPI, Ac-DEVD-pNA, z-VAD-FMK were from Sigma-Aldrich. Nitrocellulose and PVDF membranes were from Millipore. Monoclonal antibodies of Cytochrome $c$, BAX, Bcl2, p27, NFkB-p65, $\mathrm{I} \kappa \mathrm{B} \alpha$ and $\beta$-actin were from Cell Signaling technologies and Millipore. All the other chemicals and reagents were purchased from local companies and are of molecular biology grade. Chebulagic acid was isolated from fruits of Terminalia chebula as described previously [29]. Fruit material of Terminalia chebula (Combretaceae) authenticated by Prof. K. Seshagirirao, and the dried drupes were deposited at University of Hyderabad Herbarium (UH) [University of Hyderabad, Hyderabad 500046, India] repository with Specimen No. 1006-KRRMR.

\section{Cell culture}

Retinoblastoma cells Y79 were grown in Dulbecco's modified Eagle's medium (DMEM) supplemented with 10\% (v/v) heat-inactivated FBS, $100 \mathrm{IU} / \mathrm{ml}$ penicillin, $100 \mathrm{mg} / \mathrm{ml}$ streptomycin and $2 \mathrm{mM}$ L-glutamine. Human corneal epithelial cells were grown in MEM alpha medium supplemented with EGF $(0.1 \mathrm{mg} / \mathrm{l})$ and insulin $(5 \mathrm{mg} / \mathrm{l})$. Both cultures were maintained in a humidified atmosphere with $5 \% \mathrm{CO}_{2}$ at $37^{\circ} \mathrm{C}$. The cultured cells were passed twice each week, seeding at a density of approx. $2 \times 10^{3}$ cells $/ \mathrm{ml}$. Cell viability was determined by the Trypan Blue dye exclusion method before seeding for each experiment.

\section{Cell proliferation assay}

Cell proliferation of Y79 cells with CA treatment was determined by the MTT assay. Y79 cells were seeded in 96-well plate in the presence or absence of CA (0.001, 0.01, 0.1, 0.5, $1,5,10,25,50$ and $100 \mu \mathrm{M})$ for $24 \mathrm{~h}$ at a density of $5 \times 10^{3}$ cells/well in a volume of $100 \mu \mathrm{l}$ medium. After incubation, $20 \mu \mathrm{l}$ of MTT at a concentration of $5 \mathrm{mg} / \mathrm{ml}$ was added. 
After $4 \mathrm{~h}$ incubation at $37^{\circ} \mathrm{C}, 100 \mu \mathrm{l}$ of lysis buffer was added to each well. Plates were agitated for $1 \mathrm{~min}$ and absorbance was read at $570 \mathrm{~nm}$ on a multi-well plate reader. The percentage of the inhibition of proliferation was calculated as a fraction of control (without CA treatment). To assess the effect of CA on non cancerous cells, Human corneal epithelial cells were used under similar treatment conditions.

\section{Cell morphology analysis}

Y79 cells $\left(1 \times 10^{5}\right)$ were incubated with CA $(50 \mu \mathrm{M})$ for 24 h. Cells were observed and photographed for morphological changes under a phase contrast inverted microscope.

\section{Nuclear morphology and DNA fragmentation analysis}

Y 79 cells at a density of $1 \times 10^{5}$ were grown overnight in a cell culture dish. The cells were then incubated with CA $(50 \mu \mathrm{M})$ for $24 \mathrm{~h}$. After incubation, cells were washed with $1 \times$ PBS and mounted on to the slide with the mounting medium containing DAPI. The slides were then observed for changes in nuclear morphology in an Olympus inverted fluorescence microscope. For DNA fragmentation assay, Y 79 cells $\left(5 \times 10^{6}\right.$ cells) were incubated at $37^{\circ} \mathrm{C}$ with $\mathrm{CA}$ $(50 \mu \mathrm{M})$ for $24 \mathrm{~h}$. After treatment, cells were washed in cold PBS and lysed in a buffer containing $50 \mathrm{mM}$ Tris ( $\mathrm{pH} 8.0$ ), $1 \mathrm{mM}$ EDTA and $0.2 \%$ Triton $\mathrm{X}-100$ for $20 \mathrm{~min}$ at $4^{\circ} \mathrm{C}$. After centrifugation at $14000 \mathrm{~g}$ for $15 \mathrm{~min}$, the supernatant was treated with proteinase $\mathrm{K}(0.5 \mathrm{mg} / \mathrm{ml})$ and $1 \%$ SDS for $1 \mathrm{~h}$ at $50^{\circ} \mathrm{C}$. DNA was extracted twice with phenol and precipitated with $140 \mathrm{mM} \mathrm{NaCl}$ and 2 volumes of ethanol at $-20^{\circ} \mathrm{C}$ overnight. DNA precipitates were washed twice in $70 \%(\mathrm{v} / \mathrm{v})$ ethanol, dissolved in TE buffer, and treated for $1 \mathrm{~h}$ at $37^{\circ} \mathrm{C}$ with RNase A. Finally, DNA preparations were electrophoresed in $1 \%$ agarose gel, stained with ethidium bromide and observed under UV light.

\section{Cell cycle analysis by flow cytometer}

Y 79 cells were seeded at a density of $4 \times 10^{5}$ in 6-well culture plates, grown overnight in medium containing $10 \%$ FBS with or without CA $(50 \mu \mathrm{M})$ for $24 \mathrm{~h}$. After treatment cells were washed with $1 \times$ PBS. For the cell cycle analysis, cells were fixed in $70 \%$ ice cold ethanol, washed with $1 \times$ PBS, incubated with RNase A $(0.1 \mathrm{mg} / \mathrm{ml})$ and stained with propidium iodide (PI) $(50 \mathrm{mg} / \mathrm{ml})$. Flow cytometric analyses were performed by using a BD Calibur machine (San Jose, CA, U.S.A.) as previously described [38]. The fluorescence intensity of PI was detected with FL2-H detector. X axis on the histogram represents PI fluorescence intensity and Y axis represents number of cells at particular fluorescence intensity.

Measurement of mitochondrial membrane potential (MMP) Y79 cells, at a density of $4 \times 10^{5}$ were seeded in 6-well culture plates and cultured with or without CA $(50 \mu \mathrm{M})$ for
$24 \mathrm{~h}$. After the treatment, cells were incubated with Rhodamine $123(10 \mu \mathrm{g} / \mathrm{ml})$ for $30 \mathrm{~min}$. After the incubation, cells were washed with $1 \times$ PBS. MMP was assessed on a flow cytometer. Data were collected using the data acquisition program CELL Questpro and fluorescence was measured using an FL-1H detector as previously described [38]. Ten thousand cells were analysed per sample. The fluorescence intensity of Rhodamine was detected with FL1-H detector. $\mathrm{X}$ axis on the dot plot represents Rhodamine fluorescence intensity and $\mathrm{Y}$ axis represents SSC-H (side scatter) indicating the granular content of the cells.

\section{Assessment of caspase 3 activity}

Caspase- 3 activity in the lysates of Y79 cells treated with CA $(50 \mu \mathrm{M})$ and untreated cells. $100 \mu \mathrm{g}$ of total protein was incubated with Caspase 3 specific peptide (Ac-DEVDpNA) at a final concentration of $200 \mu \mathrm{M}$ at $37^{\circ} \mathrm{C}$ for $2 \mathrm{~h}$ in dark. The absorbance was read at $400 \mathrm{~nm}$. Cells were pretreated with a pan-caspase inhibitor (z-VAD-FMK) for $3 \mathrm{~h}$ at a concentration $20 \mu \mathrm{M}$ before the cells were treated with CA $(50 \mu \mathrm{M})$ and cell proliferation was estimated by MTT assay.

\section{Western blotting}

Y79 cells were seeded at a density of $5 \times 10^{6}$ in $100 \mathrm{~mm}$ culture dishes. They were incubated with CA $(50 \mu \mathrm{M})$ for $0,3,6,12,24$ and $48 \mathrm{~h}$. After incubation with CA, cells were washed with $1 \times$ PBS and suspended in cell lysis buffer with $1 \mathrm{mM}$ PMSF, $10 \mu \mathrm{g} / \mathrm{ml}$ leupeptin, $20 \mu \mathrm{g} / \mathrm{ml}$ aprotinin and phosphatase inhibitor cocktail. After $30 \mathrm{~min}$ of intermittent vortexing at $4^{\circ} \mathrm{C}$, the cell lysate was centrifuged (10 $000 \mathrm{~g}$ ) for $30 \mathrm{~min}$, and the supernatant were used as the whole cell extract. Nuclear and cytoplasmic extracts were also prepared as described previously [39]. The protein content was estimated by the Bradford method [40]. $100 \mu \mathrm{g}$ of either total or nuclear or cytosolic protein from each treatment were resolved on 7-12\% SDS PAGE gels along with protein molecular weight markers and then transferred on to nitrocellulose or PVDF membranes. Membranes were stained with $0.5 \%$ ponceau stain to check the transfer. The membranes were blocked with $5 \%(\mathrm{w} / \mathrm{v})$ BSA and then incubated with the primary antibodies [BAX (1:250 dilution), Bcl-2,(1:500 dilution), Cytochrome $c$ (1:250 dilution), p27 (1:500 dilution), NFKB-p65 (1:500 dilution), Iא $\mathrm{B} \alpha$ (1:500 dilution), $\beta$-actin (1:1000 dilution)] in $10 \mathrm{ml}$ of antibody-dilution buffer $(1 \times$ Tris-buffered saline and $0.05 \%$ Tween 20 with $1 \%$ BSA) with gentle shaking at $4^{\circ} \mathrm{C}$ for 8-12 $\mathrm{h}$ and then incubated with peroxidase or alkaline phosphatase conjugated secondary antibodies. The signals were detected by using peroxidase or alkaline phosphatase substrates. The band intensity was quantified by Image J software. 


\section{Statistical analysis}

Results are reported as the Mean \pm S. E. M. for three independent experiments. Statistical analysis was carried out by Student's t test. A p-value of less than 0.01 for each concentration versus control was considered to indicate significance.

\section{Results}

Y79 cell proliferation was inhibited by CA

Y79 cells were treated with CA $(0.001,0.01,0.1,0.5,1,5,10$, 25,50 and $100 \mu \mathrm{M}$ ) for $24 \mathrm{~h}$ and cell proliferation was determined by the MTT assay. CA treatment decreased the proliferation of $\mathrm{Y} 79$ cells in a dose dependent manner. At a concentration of $50 \mu \mathrm{M}$ of CA, a $50 \%$ decrease in Y79 cell proliferation was observed (Figure 1) in $24 \mathrm{~h}$. Normal human corneal epithelial (HCE) cells were treated with CA at same concentration as that of Y79 cell treatment. CA at $50 \mu \mathrm{M}$ concentration could inhibit only $20 \%$ of HCE cell proliferation compared to $50 \%$ in Y79 cells. Further experiments were carried out with $50 \mu \mathrm{M}$ CA as $50 \%$ inhibition of Y79 cell proliferation was observed at this concentration.

\section{Y79 cell morphology altered with CA treatment}

Treatment of cells with cell death inducing agents alters the morphology of cells. Disruption of membrane and formation of membrane blebs are commonly observed. Untreated Y79 cells grow in grape like clusters (Figure 2A), but with CA treatment, morphology and growth pattern of the cells changed considerably. Y79 cells with CA treatment showed distorted morphology, membrane blebs and less clusters (Figure 2B).

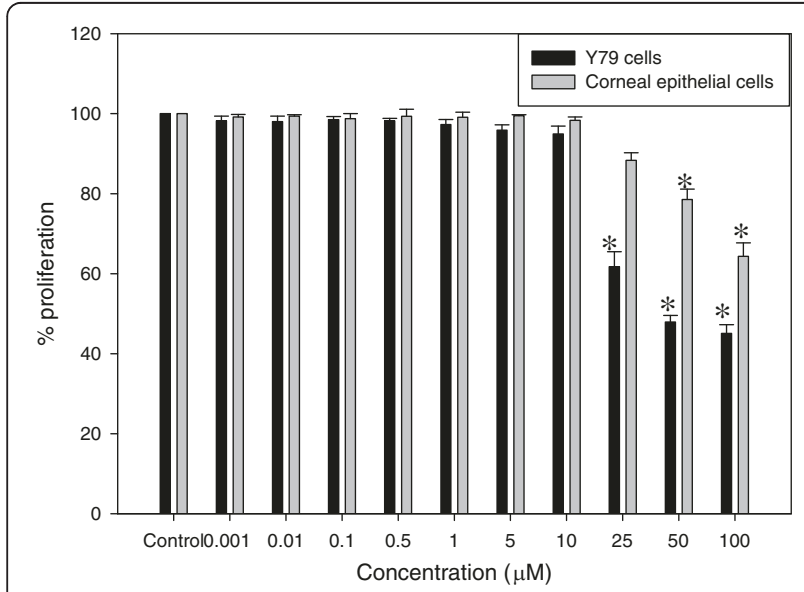

Figure 1 Effect of CA on the proliferation of retinoblastoma and normal human corneal epithelial cells. Y79 and HCE cells were treated with $0.001,0.01,0.1,0.5,1,5,10,25,50$ and $100 \mu \mathrm{M}$ concentration of CA for $24 \mathrm{~h}$. The percentage of viable cells with treatment was calculated in comparison with untreated control cells. The number of cells in the control was taken as 100\%. Data was represented as mean \pm S.E.M of three independent experiments. ${ }^{*} \mathrm{P}<0.01$ vs untreated control was considered to indicate significance.
(A)

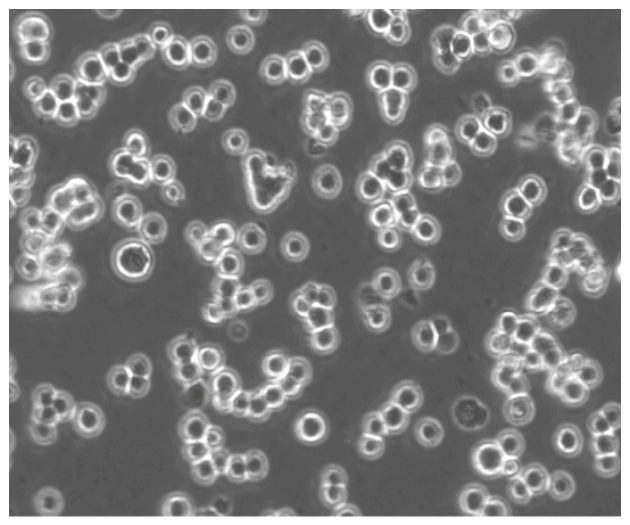

(B)

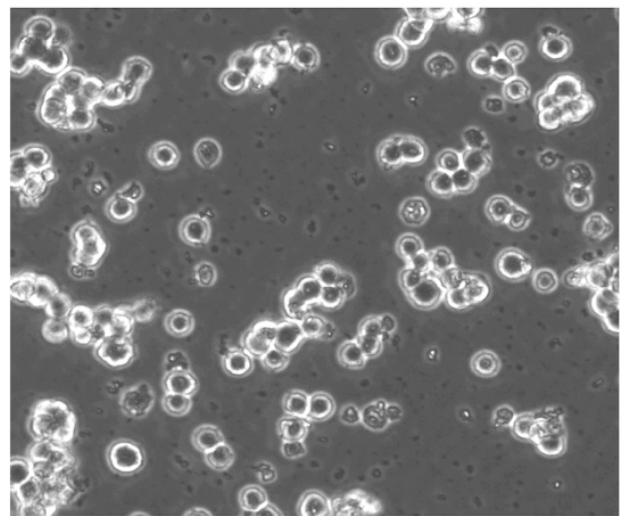

Figure 2 Effect of CA on morphology of Y79 cells. (A) Control cells (B) CA (50 $\mu \mathrm{M} ; 24 \mathrm{~h})$ treated cells.

CA induced nuclear and DNA fragmentation in Y 79 cells Nuclear fragmentation, which is observed during apoptosis, is observed using a nuclear stain DAPI. In CA $(50 \mu \mathrm{M})$ treated cells, fragmented nuclei were observed (Figure 3B) and the nuclei were intact in untreated control cells (Figure 3A). Cells treated with CA $(50 \mu \mathrm{M})$ showed fragmentation of DNA, similar to the cells undergoing apoptosis (Figure 3C).

\section{Mitochondrial membrane depolarization was observed with CA treatment}

Mitochondria play a key role in apoptosis. A change in the membrane potential of mitochondria is a critical step in the induction of apoptosis. MMP was assessed using Rhodamine 123 by flow cytometric analysis. In Figure 4, X represents $\mathrm{FL} 1-\mathrm{H}$, detector for Rhodamine in the flow cytometer. Y represents SSC-H, detector for granularity of cells. The cells on the higher scale of FL1-H represent cells with higher membrane potential. In control untreated cells majority of cells are on higher FL1H scale (Figure 4A). Treatment with CA $50 \mu \mathrm{M}$, induced a shift in the significant cell population towards the lower scale of 
(A)

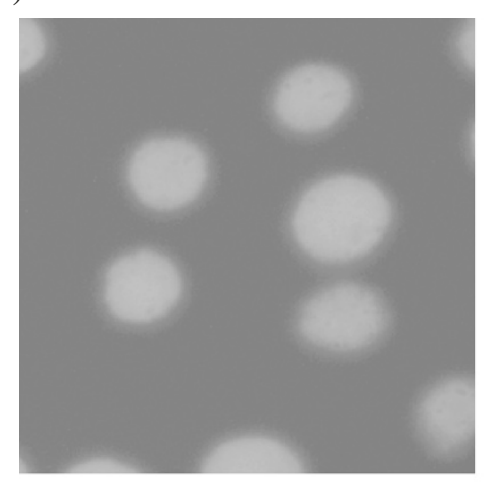

(C)

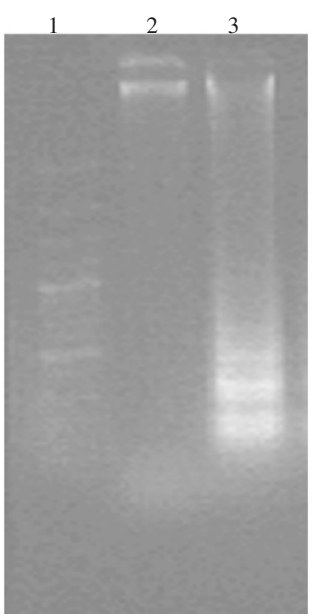

(B)

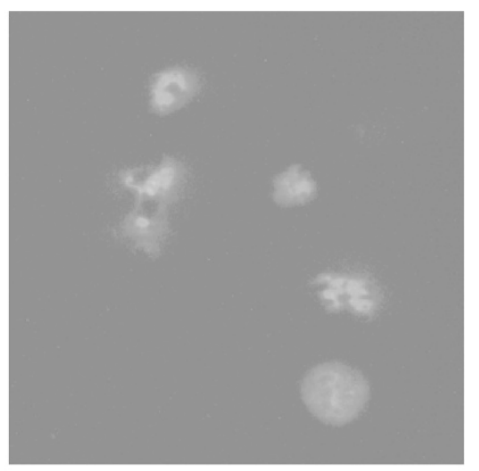

Figure 3 Effect of CA on nucleus morphology and DNA fragmentation of Y79 cells. (A) DAPI stained nucleus of control cells (B) DAPI

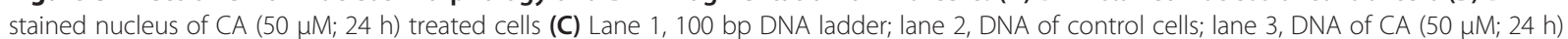
treated cells.

the FL1-H indicating depolarization of mitochondria (Figure 4B) and the treatment also resulted in decrease in cell granularity i.e. SSC-H, due to cell death.

\section{Ratio of $\mathrm{BCl} 2$ and BAX shifted towards apoptosis with CA treatment}

Ratio of $\mathrm{Bcl} 2$ and BAX proteins decides the fate of the cells towards cell survival or cell death. Due to the decrease in the expression of anti-apoptotic protein $\mathrm{Bcl} 2$ and increase of expression of pro-apoptotic protein BAX, the cells die of apoptosis. Y79 cells treated with CA $(50 \mu \mathrm{M})$ showed a time dependent increase in expression of BAX (Figure 5A) and decrease in expression of $\mathrm{Bcl} 2$ until $24 \mathrm{~h}$ and total absence at 48 and $72 \mathrm{~h}$ (Figure 5B).

\section{CA induced the release of Cytochrome $c$}

Release of Cytochrome $c$ into the cytosol as a result of mitochondrial depolarization initiates the intrinsic pathway of apoptosis. Western blot analysis with the cytoplasmic extracts devoid of mitochondria with anti-Cytochrome $c$ antibodies was performed. A time dependent increase in
Cytochrome $c$ release in Y79 cells treated with CA $(50 \mu \mathrm{M})$ was observed (Figure 5C). Untreated cells showed no release of Cytochrome $c$.

\section{CA induced apoptosis is Caspase 3 dependent}

Caspase-3 activity increased in the lysates of Y79 cells treated with CA $(50 \mu \mathrm{M})$ compared to that in untreated cells (Figure 6A). To show that CA induced cell death is caspase 3 dependent, MTT assay was done with CA, in the presence and absence of a pan-caspase inhibitor (z-VAD-FMK). Caspase inhibitor could inhibit the CA induced cell death in Y 79 cells (Figure 6B).

\section{CA treatment increased the number of $Y 79$ cells in hypodiploid and G1 phases}

Number of hypodiploid cells increases with apoptosis. Induction of apoptosis with CA treatment was quantified by flowcytometric analysis. X represents FL2-H, detector for Propidium Iodide in the flow cytometer. Y represents counts, representing number of cells at particular FL2-H. Propidium Iodide is a DNA binding dye and proportion of 


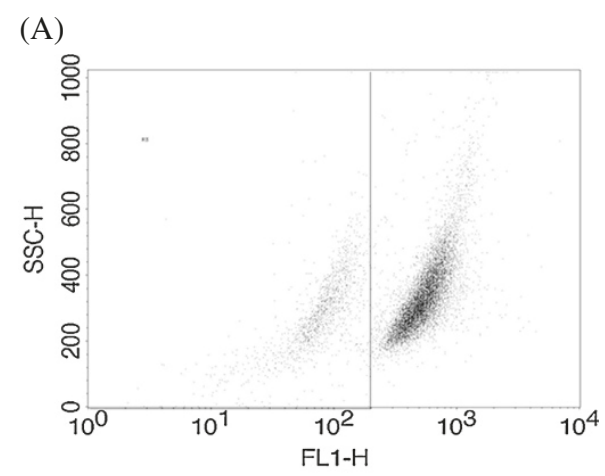

(B)

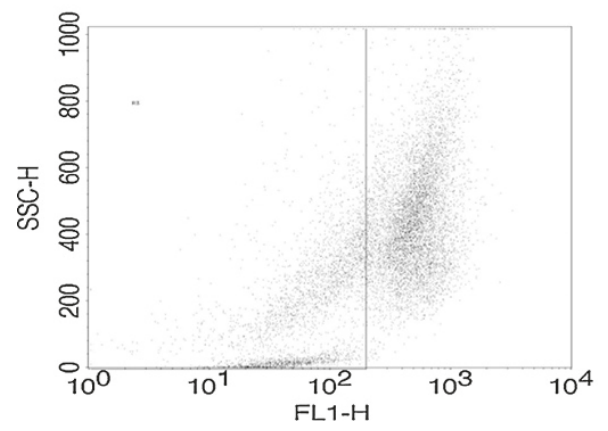

Figure 4 Effect of CA on mitochondrial membrane potential of Y79 cells. Cells were treated with CA (50 $\mu \mathrm{M})$ for $24 \mathrm{~h}$ and incubated with Rhodamine $123(10 \mu \mathrm{g} / \mathrm{ml})$ for $30 \mathrm{~min}$ fluorescence was quantified by FACS. (A) Control cells (B) CA (50 $\mu \mathrm{M} ; 24$ h) treated cells.

fluorescence emission is based on quantity of DNA in the cell. In a dividing cells, the quantity of DNA in different phases of cell cycle varies as $\mathrm{G} 1<\mathrm{S}<\mathrm{G} 2 / \mathrm{M}$. The marker (M1) represents the cells before G1 peak, indicating the cells which are having less DNA (hypodiploid) than G1 phase cells. These hypodiploid cells are the cells undergoing cell death. In the Figure 6, we can clearly observe, the increase in number of cells before G1 peak with CA $(50 \mu \mathrm{M})$ treatment compared to untreated cells. Untreated control cells showed prominent G1 (59\%), S (12\%) and G2/M (27\%) phases with minimal 1\% in sub G1 hypodiploid stage (Figure 7A). Treatment with CA increased the\% of cells in sub G1 phase and G1 phase to $12 \%$ and $76 \%$ respectively (Figure $7 \mathrm{~B}$ ). These results indicate that $\mathrm{CA}$ treatment arrested the cells in G1 stage of cell cycle and also induced apoptosis.

\section{CA induces $\mathrm{G} 1$ arrest and inhibits NFKB}

p27 and NFKB are important regulators of cell cycle progression and proliferation. As increase in\% of cells in G1 phase was observed, the expression levels of p27 were estimated. With CA $(50 \mu \mathrm{M})$ treatment, a time dependent increase in expression of p27 was observed (Figure $8 \mathrm{C}$ ), indicating CA mediated G1 arrest is through p27. Levels of $\mathrm{NFKB}$ are altered with proliferative status of cells. NFkB-p65 levels decreased in the nuclear extracts of Y79

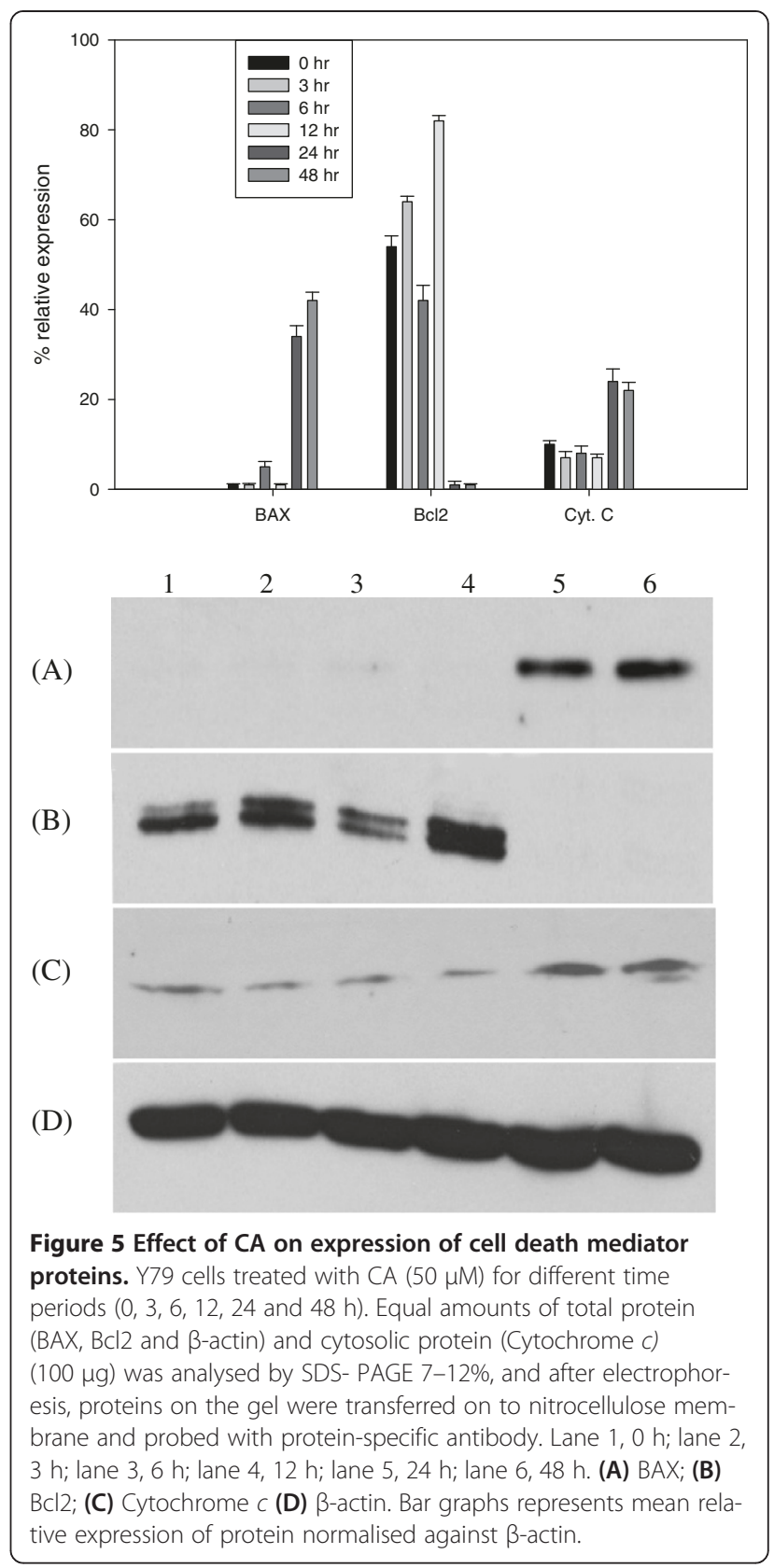

cells with CA treatment (Figure 8A), where as IkB $\alpha$ levels increased (Figure $8 \mathrm{~B}$ ). These results indicate CA suppressed the degradation of $\mathrm{I} \kappa \mathrm{B} \alpha$, there by inhibiting the translocation of $\mathrm{NF} \kappa \mathrm{B}$ to nucleus.

\section{Discussion}

Plants are the source of many clinically used potent anti-cancer molecules [1]. The enormous diversity of the plants was not explored and screened extensively for potential therapeutic molecules [41,42]. Exploration of plants for natural products even makes it more relevant these days, with the advances in the methods and technologies to prepare analogs from the isolated natural 


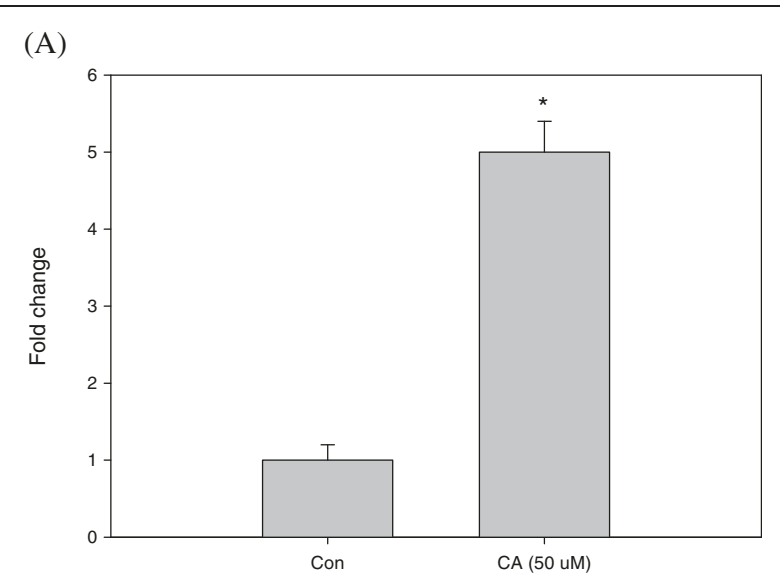

(B)

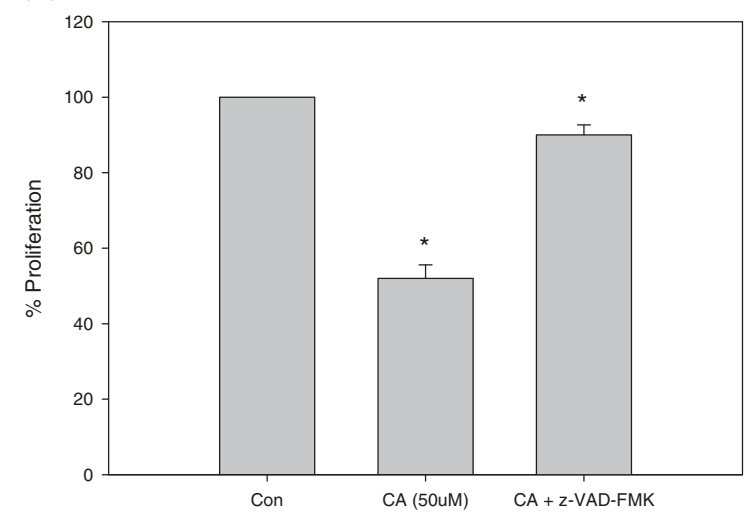

Figure 6 Effect of CA on activation of caspase 3. (A) Cells were treated with $C A(50 \mu \mathrm{M})$ for $24 \mathrm{~h}$, and lysates were analysed for caspase 3 activation. (B) Proliferation of CA (50 $\mu \mathrm{M})$ treated $Y 79$ cells for $24 \mathrm{~h}$ in the presence and absence of pan caspase inhibitor, z-VAD-FMK.

products [43]. Our previous reports have shown the anti-cancer properties of natural products isolated from various sources [44-46]. Our group has shown CA isolated from Terminalia chebula inhibits LPS induced inflammation [28], inhibits proliferation of colon cancer cells [29]. In addition to these properties several groups have shown beneficial properties of CA [33-37]. Current therapies to retinoblastoma are limited necessitating the patient to undergo enucleation. Due to several medicinal properties of CA, the present study is planned to understand the effect of CA on retinoblastoma cell line, Y79, and to understand the molecular mechanisms involved.

Y79 cells when treated with CA showed a dose dependent inhibition of cell proliferation. We observed 50\% inhibition of Y79 cell proliferation at $50 \mu \mathrm{M}$ concentration of CA. At the same concentration CA could only inhibit $20 \%$ proliferation of normal HCE cells. This indicates CA is more specific towards cancer cells. These differential effects of CA on cell proliferation between cancer and normal cells might be due to differences in constituent expression of the cellular protein signatures like constitutive NFkB expression [26].

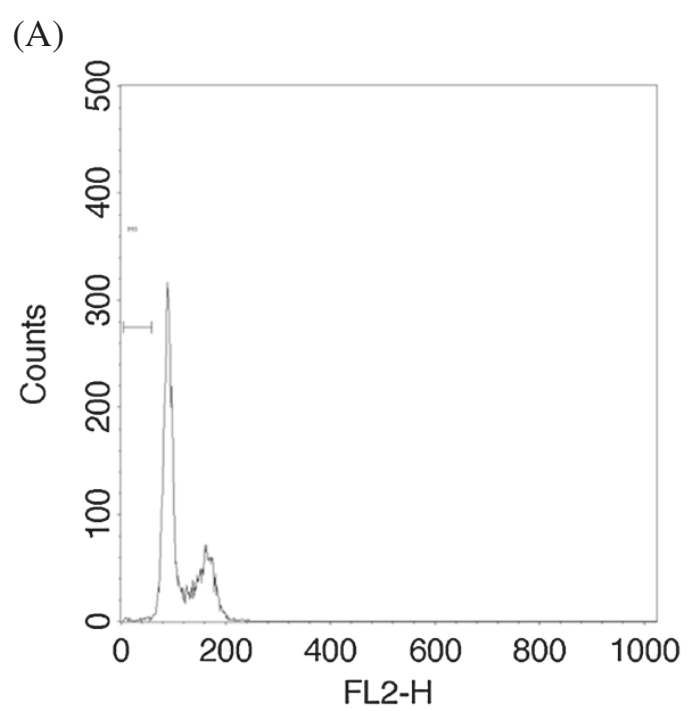

(B)

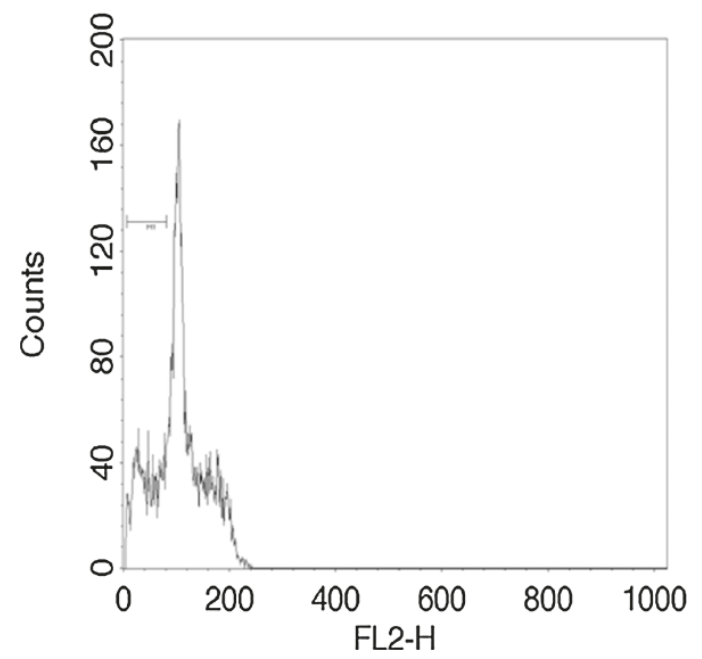

Figure 7 Effect of CA on the cell cycle of Y79 cells. Cells were treated with $\mathrm{CA}(50 \mu \mathrm{M})$ for $24 \mathrm{~h}$, fixed, and stained with propidium iodide, and the DNA content was quantified by FACS. The number of cells in hypodiploid (subG0/G1) and G1 phase is expressed as a percentage of the total number of cells. (A) Control cells (B) CA $(50 \mu \mathrm{M} ; 24 \mathrm{~h})$ treated cells.

Retinoblastoma cells grow in clusters, but with the CA treatment, the morphology and growth pattern of the cells changed considerably. Y79 cells with CA treatment showed distorted morphology, membrane blebs and less cell clusters. Nuclear and DNA fragmentation, a hallmark property of cells undergoing apoptosis, was observed in Y79 cells with CA treatment.

MMP is critical for proper cellular functions. Depolarized mitochondria lead to leakage of the membrane leading to release of Cytochrome $c$ and formation of apoptosome complex [47]. Rhodamine 123 was used to assess the MMP in CA treated Y79 cells by flowcytometric analysis. Treatment with CA decreased the MMP of the retinoblastoma 


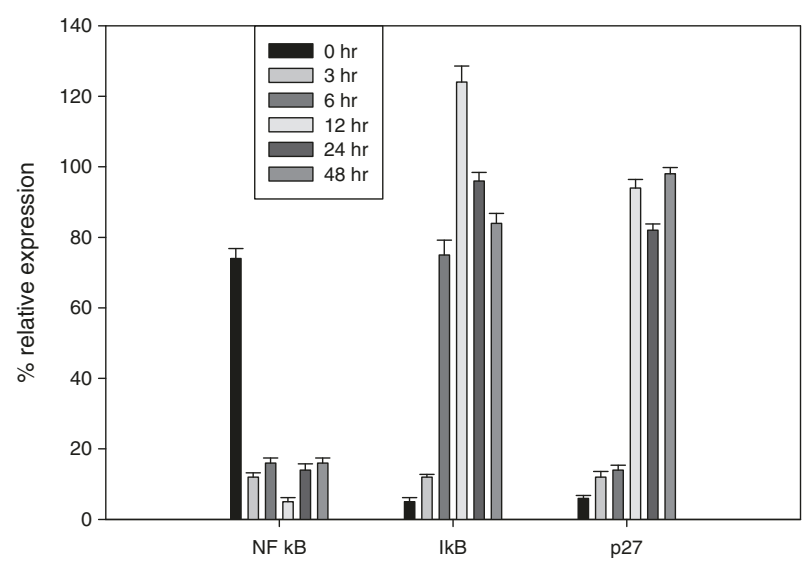

(A)

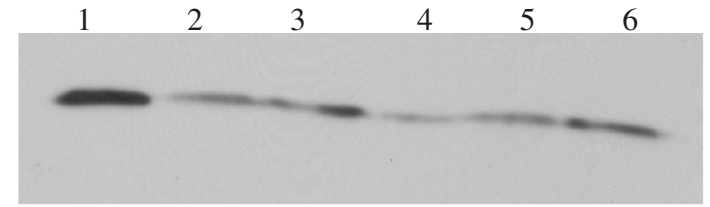

(B)

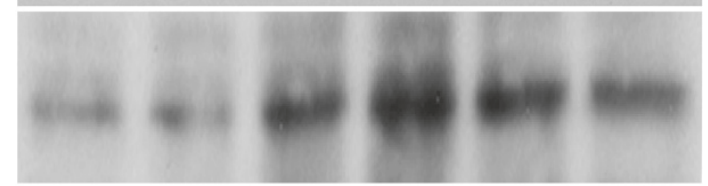

(C)

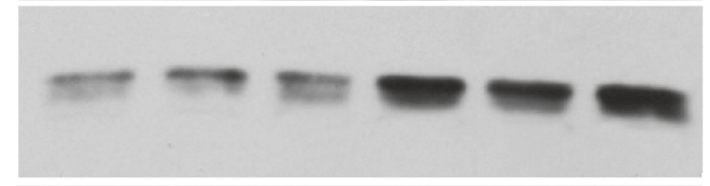

(D)

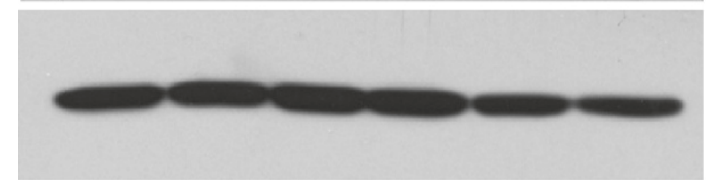

Figure 8 Effect of CA on the expression of NFKB-p65, IKBa and p27 proteins. Y79 cells treated with CA (50 $\mu \mathrm{M})$ for different time periods $(0,3,6,12,24$ and $48 \mathrm{~h}$ ). Equal amounts of total protein ( $\mathrm{k} \mathrm{KBa}, \mathrm{p} 27 \mathrm{and} \beta$-actin) and nuclear protein (NFKB-p65) (100 $\mu \mathrm{g})$ was analysed by SDS- PAGE 7-12\%, and after electrophoresis, proteins on the gel were transferred on to nitrocellulose membrane and probed with NFKB-p65, IkBa, p27and $\beta$-actin specific antibodies. Lane 1, 0 h; lane 2, 3 h; lane 3, 6 h; lane 4, 12 h; lane 5, 24 h; lane 6, 48 h. Bar graphs represents mean relative expression of protein normalised against $\beta$-actin. (A) NFkB-p65, (B) IkBa, (C) p27, (D) $\beta$-actin.

cells, indicated by the movement of cells towards lower scale on $\mathrm{x}$ axis of the dot plot. This disruption of MMP might alter the membrane dynamics of mitochondria leading to the molecular events triggering cell death. Similar disruption in membrane potential was observed with methanolic extracts of Gracilaria tenuistipitata in oral cancer cells $[38,48]$.

Bcl2 family members regulate the mitochondrial pathway of apoptosis. They are either pro apoptotic (Bak or $\mathrm{Bax})$ or anti apoptotic ( $\mathrm{Bcl} 2$ or $\mathrm{Bcl} \mathrm{XL})$. These proteins play role in permeabilization of the mitochondrial outer membrane on receiving apoptotic signals. Permeabilization leads to release of Cytochrome $c$, formation of apoptosome complex, activation of caspases, thus triggering morphological changes like membrane blebbing and nuclear fragmentation. Expression ratio of pro apoptotic BAX and anti apoptotic $\mathrm{Bcl} 2$ is the critical factor in driving cells towards life or death. Cells undergoing apoptosis show an increase in the expression of BAX and a decrease in the expression of $\mathrm{Bcl} 2$. $7 \alpha$-hydroxy- $\beta$-sitosterol, a natural phytosterol oxide was shown to induce apoptosis by altering $\mathrm{Bcl} 2 / \mathrm{BAX}$ ratio [49]. In our study, Y79 cells treated with CA shifted the ratio of $\mathrm{Bcl} 2$ and $\mathrm{BAX}$ towards cell death by increasing expression of BAX and decreasing the expression of $\mathrm{Bcl} 2$, release of cytochrome $\mathrm{c}$ and activation of caspase 3.

$\mathrm{NF}_{\mathrm{B}} \mathrm{B}$ is a proliferating promoting protein and is activated in majority of tumors. $\mathrm{NFKB}_{\mathrm{K}}$ translocates to the nucleus and activates transcription of several genes which are involved in cell proliferation. $\mathrm{Bcl} 2$ expression is 
defective in B cells that lack constituent proteins of NFKB indicating anti apoptotic $\mathrm{Bcl} 2$ might be regulated by $\mathrm{NFkB}$ [24]. The activation of $N F \kappa B$ is regulated by IкB $\alpha$. We

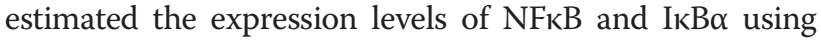
western blotting. Treatment of retinoblastoma cells with $\mathrm{CA}$ inhibited the translocation of $\mathrm{NFKB}$ to the nucleus. CA suppressed the degradation of ІкB $\alpha$. This increase in

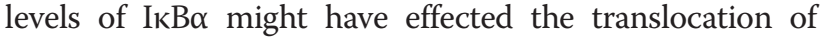
$\mathrm{NF \kappa} B$ to nucleus, effecting expression of several genes involved in Y79 cell proliferation. Similar NFkB mediated inhibition of cell proliferation was shown by natural products and plant extracts [50,51].

Most of the anti cancer agents target the cell cycle of the cancer cells and this property to alter the cell cycle is considered one of the important property in the anti cancer drug development [52]. Progression of cell cycle is regulated by CDK inhibitor, p27. Increase in the expression of p27 inhibits the cell cycle entry into S phase [25]. Cell cycle analysis of the Y79 cells treated with CA showed an increase apoptotic or hypodiploid cells. We could also observe an increase in number of cells in G1 phase with CA treatment. Western blot analysis of p27 also showed a time dependent increase in expression, which indicates that CA induces G1 arrest by the induction of p27 expression. The present study thus demonstrates that CA induces apoptosis in retinoblastoma cell line Y79 by altering expression of Bcl2 family members, activating caspase 3 , disrupting MMP and interfering with the NFKB cell proliferation pathway (Figure 9).

\section{Conclusions}

Our findings clearly demonstrate that CA induces G1 arrest, inhibits $\mathrm{NFK}_{\mathrm{K}} \mathrm{B}$ and induces apoptosis of retinoblastoma Y79 cells. CA induced the release of Cytochrome $c$ by

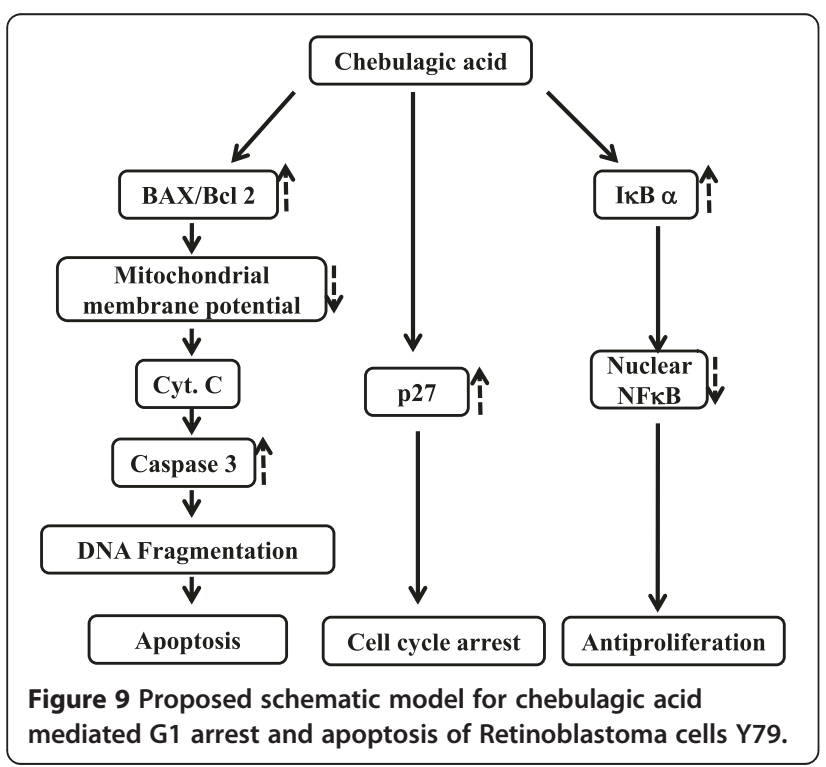

modulating the MMP and altering $\mathrm{BAX}$ and $\mathrm{Bcl} 2$ ratio towards apoptosis. CA induced apoptosis of Y79 cells is caspase 3 dependent. G1 arrest in the Y79 cells with CA treatment is mediated by the increase in the expression of CDK inhibitor p27. CA inhibited the nuclear translocation of $\mathrm{NF}_{\kappa} \mathrm{B}$ by suppressing the degradation of IкB $\alpha$. This study highlights the potential of $\mathrm{CA}$ in inhibiting the proliferation of retinoblastoma cells. Further studies are required to assess the in vivo anti proliferative potential of CA. CA and any other analogs derived from it may be explored and validated further for its usefulness as anti cancer agents for retinoblastoma and other cancers.

\section{Abbreviations}

CA: Chebulagic acid; CDK: Cyclin dependent kinase; COX: Cyclooxygenase: LOX: Lipoxygenase; FBS: Fetal bovine serum; DMEM: Dulbecco's modified eagle's medium; PBS: Phosphate buffered saline; MMP: Mitochondrial membrane potential.

\section{Competing interests}

The authors declare that they have no competing interests.

\section{Authors' contributions}

NK and GD carried out all the experiments, acquisition and analysis of data. GG was involved in cell culturing, MTT assay, Western blotting. RK conceived, designed, analysed and drafted the manuscript. All authors have read and approved the final manuscript.

\section{Acknowledgements}

This research is supported by grants from DST-SERB (No.SR/FT/LS-157/2010) to R. K. The research is done using DST-FIST supported infrastructural facilities. We are thankful to Lena Franziska Feige, University of Munster for her help in language corrections.

Received: 29 June 2013 Accepted: 20 August 2014

Published: 29 August 2014

\section{References}

1. Butler MS: Natural products to drugs: natural product-derived compounds in clinical trials. Nat Prod Rep 2008, 25:475-516.

2. Newman DJ, Cragg GM: Natural products as sources of new drugs over the last 25 years. J Nat Prod 2007, 70:461-477.

3. Pak RW, Lanteri VJ, Scheuch JR, Sawczuk IS: Review of vitamin E and selenium in the prevention of prostate cancer: implications of the selenium and vitamin E chemoprevention trial. Integr Cancer Ther 2002, 1:338-344.

4. Vainio $H$, Weiderpass E: Fruit and vegetables in cancer prevention. Nutr Cancer 2006, 54:111-142.

5. Nakahata N, Kutsuwa M, Kyo R, Kubo M, Hayashi K, Ohizumi Y: Analysis of inhibitory effects of scutellariae radix and baicalein on prostaglandin E2 production in rat C6 glioma cells. Am J Chin Med 1998, 26:311-323.

6. Paiva SA, Russell RM: Beta-carotene and other carotenoids as antioxidants. J Am Coll Nutr 1999, 18:426-433.

7. Kale A, Gawande S, Kotwal S, Netke S, Roomi MW, Ivanov V, Niedzwiecki A, Rath M: A combination of green tea extract, specific nutrient mixture and quercetin: An effective intervention treatment for the regression of $\mathrm{N}$-methyl-N-nitrosourea (MNU)-induced mammary tumors in Wistar rats. Oncol Lett 2010, 1:313-317.

8. Abdulla M, Gruber P: Role of diet modification in cancer prevention. Biofactors 2000, 12:45-51.

9. Zuzak TJ, Rist L, Eggenschwiler J, Grotzer MA, Viviani A: Pediatric medulloblastoma cells are susceptible to Viscum album (Mistletoe) preparations. Anticancer Res 2006, 26:3485-3492.

10. Gul MZ, Bhakshu LM, Ahmad F, Kondapi AK, Qureshi IA, Ghazi IA: Evaluation of Abelmoschus moschatus extracts for antioxidant, free radical scavenging, antimicrobial and antiproliferative activities using in vitro assays. BMC Complement Altern Med 2011, 11:64. 
11. Antczak C, Kloepping C, Radu C, Genski T, Müller-Kuhrt L, Siems K, de Stanchina E, Abramson DH, Djaballah H: Revisiting old drugs as novel agents for retinoblastoma: in vitro and in vivo antitumor activity of cardenolides. Invest Ophthalmol Vis Sci 2009, 50:3065-3073.

12. D'Anneo A, Augello G, Santulli A, Giuliano M, di Fiore R, Messina C, Tesoriere G, Vento R: Paclitaxel and beta-lapachone synergistically induce apoptosis in human retinoblastoma Y79 cells by downregulating the levels of phosphoAkt. J Cell Physiol 2010, 222:433-443.

13. De Potter P: Current treatment of retinoblastoma. Curr Opin Ophthalmol 2002, 13:331-336.

14. Abramson DH: Retinoblastoma in the 20th century: past success and future challenges the Weisenfeld lecture. Invest Ophthalmol Vis Sci 2005, 46:2683-2691.

15. Brichard B, De Bruycker JJ, De Potter P, Neven B, Vermylen C, Cornu G: Combined chemotherapy and local treatment in the management of intraocular retinoblastoma. Med Pediatr Oncol 2002, 38:411-415.

16. Benz MS, Scott IU, Murray TG, Kramer D, Toledano S: Complications of systemic chemotherapy as treatment of retinoblastoma. Arch Ophthalmol 2000, 118:577-578.

17. Beck MN, Balmer A, Dessing C, Pica A, Munier F: First-line chemotherapy with local treatment can prevent external-beam irradiation and enucleation in low-stage intraocular retinoblastoma. J Clin Oncol 2000, 18:2881-2887.

18. Friedman DL, Himelstein B, Shields CL, Shields JA, Needle M, Miller D, Bunin GR, Meadows AT: Chemoreduction and local ophthalmic therapy for intraocular retinoblastoma. J Clin Oncol 2000, 18:12-17.

19. Rizzuti AE, Dunkel IJ, Abramson DH: The adverse events of chemotherapy for retinoblastoma: what are they? Do we know? Arch Ophthalmol 2008, 126:862-865.

20. Klein G, Michaelis J, Spix C, Wibbing R, Eggers G, Ritter J, Kaatsch P: Second malignant neoplasms after treatment of childhood cancer. Eur J Cancer 2003, 39:808-817.

21. Nishimura S, Sato T, Ueda H, Ueda K: Acute myeloblastic leukemia as a second malignancy in a patient with hereditary retinoblastoma. $J$ Clin Oncol 2001, 19:4182-4183.

22. Chantada G, Fandiño A, Casak S, Manzitti J, Raslawski E, Schvartzman E: Treatment of overt extraocular retinoblastoma. Med Pediatr Oncol 2003, 40:158-161.

23. Karin M, Lin A: NF-kappaB at the crossroads of life and death. Nat Immunol 2002, 3:221-227.

24. Grossmann M, O'Reilly LA, Gugasyan R, Strasser A, Adams JM, Gerondakis S: The anti-apoptotic activities of Rel and RelA required during B-cell maturation involve the regulation of $\mathrm{BCl}-2$ expression. EMBO J 2000, 19:6351-6360.

25. Schwartz GK, Shah MA: Targeting the cell cycle: a new approach to cancer therapy. J Clin Oncol 2005, 23:9408-9421.

26. Poulaki V, Mitsiades CS, Joussen AM, Lappas A, Kirchhof B, Mitsiades N: Constitutive nuclear factor-kappaB activity is crucial for human retinoblastoma cell viability. Am J Pathol 2002, 161:2229-2240.

27. Sareen D, van Ginkel PR, Takach JC, Mohiuddin A, Darjatmoko SR, Albert DM, Polans AS: Mitochondria as the primary target of resveratrol-induced apoptosis in human retinoblastoma cells. Invest Ophthalmol Vis Sci 2006, 47:3708-3716.

28. Reddy DB, Reddanna P: Chebulagic acid (CA) attenuates LPS-induced inflammation by suppressing NF-kappaB and MAPK activation in RAW 264.7 macrophages. Biochem Biophys Res Commun 2009, 381:112-117.

29. Reddy DB, Reddy TC, Jyotsna G, Sharan S, Priya N, Lakshmipathi V, Reddanna P: Chebulagic acid, a COX-LOX dual inhibitor isolated from the fruits of Terminalia chebula Retz., induces apoptosis in COLO-205 cell line. J Ethnopharmacol 2009, 124:506-512.

30. Cheng HY, Lin TC, Yu KH, Yang CM, Lin CC: Antioxidant and free radical scavenging activities of Terminalia chebula. Biol Pharm Bull 2003, 26:1331-1335

31. lason $\mathrm{G}$ : The role of plant secondary metabolites in mammalian herbivory: ecological perspectives. Proc Nutr Soc 2005, 64:123-131.

32. Khanbabaee $K$, van Ree T: Tannins: classification and definition. Nat Prod Rep 2001, 18:641-649.

33. Lee SI, Hyun PM, Kim SH, Kim KS, Lee SK, Kim BS, Maeng PJ, Lim JS: Suppression of the onset and progression of collagen-induced arthritis by chebulagic acid screened from a natural product library. Arthritis Rheum 2005, 52:345-353.

34. Huang YN, Zhao DD, Gao B, Zhong K, Zhu RX, Zhang Y, Xie WJ, Jia LR, Gao H: Anti-Hyperglycemic Effect of Chebulagic Acid from the Fruits of Terminalia chebula Retz. Int J Mol Sci 2012, 13:6320-6333.
35. Kinoshita S, Inoue $Y$, Nakama S, Ichiba T, Aniya Y: Antioxidant and hepatoprotective actions of medicinal herb, Terminalia catappa L. from Okinawa Island and its tannin corilagin. Phytomedicine 2007, 14:755-762.

36. Murakami A, Ishida H, Kobo K, Furukawa I, Ikeda Y, Yonaha M, Aniya Y, Ohigashi $H$ : Suppressive effects of Okinawan food items on free radical generation from stimulated leukocytes and identification of some active constituents: implications for the prevention of inflammation-associated carcinogenesis. Asian Pac J Cancer Prev 2005, 6:437-448.

37. Lin LT, Chen TY, Chung CY, Noyce RS, Grindley TB, McCormick C, Lin TC, Wang GH, Lin CC, Richardson CD: Hydrolyzable tannins (chebulagic acid and punicalagin) target viral glycoprotein-glycosaminoglycan interactions to inhibit herpes simplex virus 1 entry and cell-to-cell spread. J Virol 2011, 85:4386-4398.

38. Roy KR, Arunasree KM, Reddy NP, Dheeraj B, Reddy GV, Reddanna P: Alteration of mitochondrial membrane potential by Spirulina platensis C-phycocyanin induces apoptosis in the doxorubicin resistant human hepatocellularcarcinoma cell line HepG2. Biotechnol App/ Biochem 2007, 47:159-167.

39. Roy KR, Arunasree KM, Dhoot A, Aparna R, Reddy GV, Vali S, Reddanna P: C-Phycocyanin inhibits 2-acetylaminofluorene-induced expression of MDR1 in mouse macrophage cells: ROS mediated pathway determined via combination of experimental and In silico analysis. Arch Biochem Biophys 2007, 459:169-177.

40. Bradford MM: A rapid and sensitive method for the quantitation of microgram quantities of protein utilizing the principle of protein-dye binding. Anal Biochem 1976, 72:248-254

41. Harvey A: Strategies for discovering drugs from previously unexplored natural products. Drug Discov Today 2000, 5:294-300.

42. Baker DD, Chu M, Oza U, Rajgarhia V: The value of natural products to future pharmaceutical discovery. Nat Prod Rep 2007, 24:1225-1244.

43. Sunazuka T, Hirose T, Omura S: Efficient total synthesis of novel bioactive microbial metabolites. Acc Chem Res 2008, 41:302-314.

44. Nishanth RP, Ramakrishna BS, Jyotsna RG, Roy KR, Reddy GV, Reddy PK, Reddanna P: C-Phycocyanin inhibits MDR1 through reactive oxygen species and cyclooxygenase-2 mediated pathways in human hepatocellular carcinoma cell line. Eur J Pharmacol 2010, 649:74-83.

45. Roy KR, Nishanth RP, Sreekanth D, Reddy GV, Reddanna P: C-Phycocyanin ameliorates 2-acetylaminofluorene induced oxidative stress and MDR1 expression in the liver of albino mice. Hepatol Res 2008, 38:511-520.

46. Sreekanth D, Arunasree MK, Roy KR, Chandramohan Reddy T, Reddy GV, Reddanna P: Betanin a betacyanin pigment purified from fruits of Opuntia ficus-indica induces apoptosis in human chronic myeloid leukemia Cell line-K562. Phytomedicine 2007, 14:739-746.

47. Chinnaiyan AM: The apoptosome: heart and soul of the cell death machine. Neoplasia 1999, 1:5-15.

48. Yeh CC, Yang Jl, Lee JC, Tseng CN, Chan YC, Hseu YC, Tang JY, Chuang LY, Huang HW, Chang FR, Chang HW: Anti-proliferative effect of methanolic extract of Gracilaria tenuistipitata on oral cancer cells involves apoptosis, DNA damage, and oxidative stress. BMC Complement Altern Med 2012, 12:142.

49. Tasyriq M, Najmuldeen IA, In LL, Mohamad K, Awang K, Hasima N: 7aHydroxy- $\beta$-Sitosterol from Chisocheton tomentosus Induces Apoptosis via Dysregulation of Cellular Bax/Bcl-2 Ratio and Cell Cycle Arrest by Downregulating ERK1/2 Activation. Evid Based Complement Alternat Med 2012, 2012:765316

50. Deeb D, Jiang H, Gao X, Hafner MS, Wong H, Divine G, Chapman RA, Dulchavsky SA, Gautam SC: Curcumin sensitizes prostate cancer cells to tumor necrosis factor-related apoptosis-inducing ligand/Apo2L by inhibiting nuclear factor-kappaB through suppression of IkappaBalpha phosphorylation. Mol Cancer Ther 2004, 3:803-812.

51. Lopes FC, Rocha A, Pirraco A, Regasini LO, Silva DH, Bolzani VS, Azevedo I, Carlos IZ, Soares R: Anti-angiogenic effects of pterogynidine alkaloid isolated from Alchornea glandulosa. BMC Complement Altern Med 2009, 9:15.

52. Carnero A: Targeting the cell cycle for cancer therapy. Br J Cancer 2002, 87:129-133.

doi:10.1186/1472-6882-14-319

Cite this article as: Kumar et al:: Chebulagic acid from Terminalia chebula causes G1 arrest, inhibits NFKB and induces apoptosis in retinoblastoma cells. BMC Complementary and Alternative Medicine 2014 14:319. 